\title{
Effect of high frequency transcutaneous electrical nerve stimulation on viability of random skin flap in rats ${ }^{1}$
}

\author{
Efeito da estimulação elétrica nervosa transcutânea em alta freqüência na viabilidade \\ do retalho cutâneo randômico em ratos
}

\author{
Richard Eloin Liebano ${ }^{2}$, Luiz Eduardo Felipe Abla ${ }^{3}$, Lydia Masako Ferreira ${ }^{4}$ \\ 1. Study from Post-graduation Program in Reconstructive Plastic Surgery - Federal University of São Paulo - Paulista School of Medicine \\ (UNIFESP-EPM). Brazil. \\ 2. Doctor in Sciences, Plastic Surgery Program - UNIFESP-EPM. Brazil. \\ 3. Doctor in Reconstructive Plastic Surgery - UNIFESP-EPM. Brazil. \\ 4. Full Professor, Coordinator of Post-graduation Program in Reconstructive Plastic Surgery - UNIFESP-EPM. Brazil
}

\begin{abstract}
Purpose: To determine the effect of high frequency Transcutaneous Electrical Nerve Stimulation (TENS) on viability of random skin flap in rats. Methods: The sample of this study was 75 Wistar rats. The skin flap measured $10 \mathrm{x} 4 \mathrm{~cm}$ and a plastic barrier was interposed between the flap and donor site. After the operative procedure, animals of all groups were maintained anesthetized one more hour with electrodes positioned in the base of the flap and submitted to treatment according of their respective group. This procedure was repeated on the two subsequent days. G1: sham stimulation (control), G2: TENS ( $\mathrm{f}=80 \mathrm{~Hz}$ and $\mathrm{I}=5 \mathrm{~mA}$ ), G3: TENS ( $\mathrm{f}=80 \mathrm{~Hz}$ and $\mathrm{I}=10 \mathrm{~mA}), \mathrm{G} 4$ : TENS ( $\mathrm{f}=80 \mathrm{~Hz}$ and $\mathrm{I}=15 \mathrm{~mA})$, G5: TENS ( $f=80 \mathrm{~Hz}$ and $\mathrm{I}=20 \mathrm{~mA}$ ). Results: The average percentage of necrotic area was 43,11, 34,65, 49,44, 23,52, 45,10 in groups 1, 2, 3, 4 and 5 respectively. Conclusion: The amplitude of $15 \mathrm{~mA}$ presented a lower necrotic area than control group and Transcutaneous Electrical Nerve Stimulation was efficient in increasing the random skin flap viability.
\end{abstract}

Key words: Transcutaneous Electric Nerve Stimulation. Surgical Flaps. Tissue Survival. Rats.

\section{RESUMO}

Objetivo: Avaliar o efeito da Estimulação Elétrica Nervosa Transcutânea (TENS) em alta freqüência na viabilidade do retalho cutâneo randômico em ratos. Métodos: Foram utilizados 75 ratos da linhagem Wistar. O retalho cutâneo apresentava 10 x 4 cm, sendo que entre o mesmo e a área doadora foi realizada a interposição de uma barreira plástica. Após o procedimento operatório todos os animais permaneceram anestesiados por mais uma hora com os eletrodos posicionados na base do retalho e submetidos ao tratamento de acordo com seus respectivos grupos. Este procedimento se repetiu nos outros dois dias subseqüentes. G1: simulação da TENS, G2: TENS ( $\mathrm{f}=80 \mathrm{~Hz}$ e I = $5 \mathrm{~mA})$, G3: TENS $(\mathrm{f}=80 \mathrm{~Hz}$ e I = $10 \mathrm{~mA}$ ), G4: TENS ( $\mathrm{f}=80 \mathrm{~Hz}$ e I = $15 \mathrm{~mA}$ ), G5: TENS ( $\mathrm{f}=80 \mathrm{~Hz}$ e I = $20 \mathrm{~mA})$. Resultados: A porcentagem média de área de necrose foi de 43,11, 34,65, 49,44, 23,52, 45,10 nos grupos 1, 2, 3, 4 e 5 respectivamente. Conclusão: Os animais estimulados com amplitude de 15 mA apresentaram menor área de necrose quando comparados ao grupo controle e a Estimulação Elétrica Nervosa Transcutânea foi eficiente no aumento de viabilidade do retalho cutâneo randômico em ratos.

Descritores: Estimulação Elétrica Transcutânea do Nervo. Retalhos Cirúrgicos. Sobrevivência de Tecidos. Ratos.

\section{Introduction}

Skin flaps represent the most frequent resource used in the reconstructive surgery of loss of substances, which can be traumatic or postoperative procedures ${ }^{1}$. The main and more feared complication by plastic surgeons in the accomplishment of the flap is the ischemia that can develop to tissue necrosis taking a failure in proposed treatment ${ }^{2,3}$. Based on this, a considerable amount of research has been done with the aim of improving the blood flow in flaps, decreasing ischemic conditions and preventing necrosis 3,4 . In literature, there are publications that describe the use of several kinds of drugs, such as vasodilators, calcium channel blockers, prostaglandin inhibitors, anticoagulants, antiadrenergics and antioxidants ${ }^{3,5}$. Unfortunately, many of those present undesirable side effects, which make their use unviable in clinical practice ${ }^{3,6,7}$. Therefore, a new research field using non-pharmacological agents, such as acupuncture ${ }^{8}$ and electroacupuncture ${ }^{6}$, pulsed electromagnetic energy ${ }^{9}$, low-power lasers ${ }^{10}$, polarized low frequency electrical currents ${ }^{7,11-14}$ and non-polarized currents ${ }^{6,15-18}$ has emerged. Among these resources, the transcutaneous electrical nerve stimulation - TENS - has deserved detach due to its low cost and facility on application, being studied as possible method in the treatment of ischemic skin flaps, where it has presented positive results ${ }^{6,7,12,15-18}$. In spite of that, there have been found great differences on the results of scientific works as 
for physical parameters on the current used, especially in what is referred to the frequency and amplitude (intensity). Kjartansson et al. ${ }^{7}$ used frequencies of 2 and $80 \mathrm{~Hz}$ and intensities of 5 e $20 \mathrm{~mA}$ on musculocutaneous flaps in female rats and came to the conclusion that the most important is the utilization of high intensity (20 mA), no matter what frequency is used. However, Niina et al. ${ }^{6}$, trying to reproduce the results of Kjartansson et al. ${ }^{7}$ and comparing them with the electroacupuncture, used intensities of 2, 10 and $20 \mathrm{~mA}$ and frequencies of 2 and $80 \mathrm{~Hz}$ also on musculocultaneous flaps in rats. They concluded that what really matters is the utilization of high frequency $(80 \mathrm{~Hz})$, giving no importance to the current amplitude used.

This entire context demonstrates the necessity in verifying the respective relationship of the amplitude of high frequency transcutaneous electrical nerve stimulation in ischemic skin flaps.

Therefore, the present study was designed to evaluate the effect of the high frequency TENS in random skin flaps in rats.

\section{Methods}

To accomplish this work, 75 Wistar rats were used. They were adults, males, weighing from 230 to $358 \mathrm{~g}$. There was no significant statistic difference in weight among the groups. The animals were maintained in individual cages with 12:12 h light/dark cycle (lights on at 07:00 h) and temperature control $\left(24 \pm 1^{\circ} \mathrm{C}\right)$, receiving commercial ration and water ad libitum.

This research was approved by the Committee of Ethics in Research of UNIFESP/Hospital São Paulo, CEP Nº . 0380/03.

\section{Electrostimulator}

The equipment used in the experiment was Orion Tens ${ }^{\circledR}$ [Orion Aparelhos para Fisioterapia LTDA; series number: 00849], digital and controlled by microprocessor. The emitted pulses were biphasics and symmetricals. Accompanying the electric stimulator, it was used: one cable, two silicon carbon rubber electrodes $(4,2 \times 1,5 \mathrm{~cm})$, gel and adhesive ribbon for the electrodes fixation. The stimulator was checked in digital oscilloscope at the beginning and at the end of the experiments, at the electric engineering laboratory of Paulista University.

\section{Operative technique}

All animals were anesthetized with Tiletamine Chloridrate and Zolazepan Chloridrate $(50 \mathrm{mg} / \mathrm{kg}$ ) intraperitoneally during operatory procedure and electrostimulation sessions. After anesthesia induction, all rats were positioned on a plane surface with members extended and it was performed a digital tricotomy on their backs. Then it was done the planning of the flap through a plastic mould [film F-1 (polyester + polyethylene)], cut out in pattern sizes $(10 \times 4 \mathrm{~cm})$, in the animals backs and taking as limits the inferior angles of the scapulae and the superior bones of pelvis. The random skin flap with cranial base was cut by scalpel and elevated through deep fascia, including the superficial fascia, panniculus carnosus, the subcutaneous tissue and skin ${ }^{4,7,19}$. After flap elevation, a plastic barrier (film F1), with same dimensions (10x4 cm), was placed between it and the donor site ${ }^{4,19}$. The suture was realized with simple nylon $4-0$ stitches ${ }^{4,19}$.

\section{Electrostimulation treatment}

After the operative procedure, animals of all groups were maintained anesthetized one more hour with electrodes positioned in the base of the flap, with a distance of $1,5 \mathrm{~cm}$ between them, and submitted to treatment according of their respective group. This procedure was repeated on the two subsequent days, always in the same schedule and for the same period of time ${ }^{19}$. Group one (G1): sham TENS stimulation (control), group two (G2): TENS stimulation with $\mathrm{f}=80 \mathrm{~Hz}$ and $\mathrm{I}=5 \mathrm{~mA}$, group three (G3): TENS stimulation with $\mathrm{f}=80 \mathrm{~Hz}$ and $\mathrm{I}=10 \mathrm{~mA}$, group four (G4): TENS stimulation with $\mathrm{f}=80 \mathrm{~Hz}$ and $\mathrm{I}=15 \mathrm{~mA}$, group five (G5): TENS stimulation with $\mathrm{f}=80 \mathrm{~Hz}$ and $\mathrm{I}=20 \mathrm{~mA}$. The pulse duration was of $200 \mu \mathrm{s}$ in all treatment groups.

Method for estimate percentage of necrotic area in distal portion of flaps

The percentage of skin flap necrosis area was calculated on the seventh postoperative day via the paper template method described by Sasaki and Pang ${ }^{20}$. The limit between viable tissue (soft, rosy, warm and with hair skin) and necrotic tissue (stiff, dark, cool and without hair skin) was demarcated in the animals.

A mould of entire flap was then drawn and cut out in transparent paper, being checked in a precision balance $(+/$ - 0,0001g error). It was cut out from this fragment just the correspondent area to flap necrosis, which was also checked. After that, it was used the following formula:

$$
\begin{gathered}
\text { percentage of necrosis } \\
\text { area of the flap }
\end{gathered}=\frac{\begin{array}{c}
\text { weight of paper template } \\
\text { of flap necrosis }
\end{array}}{\begin{array}{c}
\text { weight of paper template } \\
\text { of total area of flap }
\end{array}} \times 100
$$

This evaluation was accomplished by an observer that didn't know to which group belonged the animal appraised.

\section{Statistical analysis}

For the data of variables involved in this study such as necrosis percentage, parametric tests were used to analyze them. Therefore, the comparison among groups with relation to the percentage of necrosis of the flaps, the test of Analysis of Variance (ANOVA) was used with a fixed factor, following by the method of multiple comparisons of Dunnett.

The significance level was fixed in $0,05(<0,05)$. When statistical calculations presented a significant value, it was marked with an asterisk (*) to characterize it. On the other cases, the nonsignificant values, the abbreviation N.S. was used. 


\section{Results}

The mean percentage of necrosis in the flaps in G1 (control) was 43,11, G2 (80 Hz 5 mA) 39,65, G3 (80 Hz 10 mA) 49,44, G4 (80 Hz $15 \mathrm{~mA})$ 23,52 and G5 (80 Hz $20 \mathrm{~mA})$ 45,10. Only the group four (G4) had a significantly lower percentage of flap necrosis than the control group $(\mathrm{p}<0,01)^{*}$. There was no statistical difference between the groups two, three and five (G2, G3 and G5) and control group (p>0,05) (N.S.). Mean percentage of flap necrosis in the five groups is shown in Figure 1. Mean percentage of flap necrosis, the standard deviation and the minimum and maximum values of all groups are shown in Table 1.

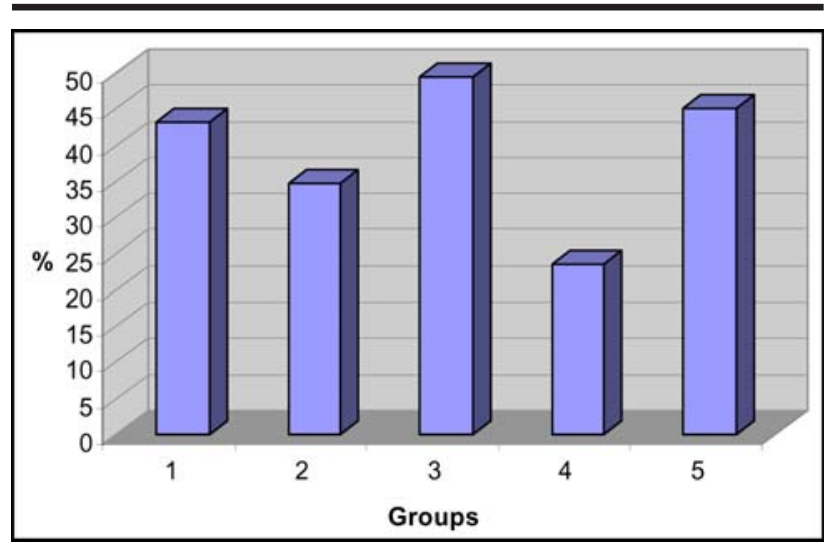

FIGURE 1 - Mean percentage value of flap necrosis in studies groups Anova - Dunnett

G1 x G2 (p > 0,05) N.S.

G1 x G3 $(p>0,05)$ N.S.

G1 x G4 $(\mathrm{p}<0,001)^{*}$

G1 x G5 (p > 0,05) N.S.

TABLE 1 - Mean percentage of flap necrosis, the standard deviation and the minimum and maximum values of all groups

\begin{tabular}{|c|c|c|c|c|c|}
\hline Group & Control (1) & $80 \mathrm{~Hz} 5 \mathrm{~mA} \mathrm{(2)}$ & $80 \mathrm{~Hz} 10 \mathrm{~mA}$ (3) & $80 \mathrm{~Hz} 15 \mathrm{~mA}(4)$ & $80 \mathrm{~Hz} 20 \mathrm{~mA}(5)$ \\
\hline $\begin{array}{l}\text { Medium } \\
\text { value (\%) }\end{array}$ & 43,11 & 39,65 & 49,44 & 23,52 & 45,10 \\
\hline Standard & & & & & \\
\hline Deviation (\%) & 9,30 & 12,29 & 15,58 & 10,83 & 16,14 \\
\hline $\begin{array}{l}\text { Minimum } \\
\text { value (\%) }\end{array}$ & 24,35 & 22,04 & 26,06 & 7,03 & 20,00 \\
\hline $\begin{array}{l}\text { Maximum } \\
\text { value (\%) }\end{array}$ & 61,92 & 45,79 & 78,04 & 39,92 & 72,75 \\
\hline
\end{tabular}

\section{Discussion}

The Transcutaneous Electrical Nerve Stimulation has been for a long time a consecrated resource in the modulation of acute and chronic pains ${ }^{21}$. More recently, some researchers began to observe, besides the analgesic effect, temperature and cutaneous blood flow alterations in healthy individuals ${ }^{22,23}$ and bearers of some diseases as Raynaud Syndrome and Diabetic Polyneuropathy 24, 25, 26. Following this important observation, TENS began to be used with the objective of accelerating the healing of ischemic ulcers with difficult repair, having as main justification the increase of the blood flow 27, 28, 29, 30 .

This knowledge motivated some authors to research the effects of this increase of blood flow caused by the electric stimulation on the viability of the ischemic skin flaps $6,7,18$. In this study using amplitude of $15 \mathrm{~mA}$, better results were obtained. These results indicate an important contribution of the amplitude in the viability of the flaps and they corroborate even more the discoveries of Kjartansson et al. ${ }^{7}$, although these authors have used different methods, mainly in what it concerns the operative procedure. The flap they used presented $7 \mathrm{~cm}$ length and 2 $\mathrm{cm}$ width, and no barrier type between the flap and the donor site. These authors used female rats in their studies, what could influence the results due to the largest hormonal variation in these animals ${ }^{7,12}$. Another difference between these studies is that, in the work of Kjartansson et al. ${ }^{7}$, only amplitudes of 5 and $20 \mathrm{~mA}$ were used, observing that the amplitude of $20 \mathrm{~mA}$ presented better results in relation to the increase of blood flow and viability of the flap. However, it is not mentioned the size of the electrodes used. The knowledge of the current amplitude or intensity without the knowledge of the electrode area makes impossible the determination of the density of the current used.

In the present study, the amplitude of $15 \mathrm{~mA}$ presented better results than the amplitude of $20 \mathrm{~mA}$. Using $20 \mathrm{~mA}$, excessively strong muscular contractions were observed, what maybe has contributed to these results. It is known that stimulations in high intensities can activate the sympathetic fibers, leading to cutaneous vasoconstriction that, theoretically, would not be favorable to the flap, considering that it is already in ischemic condition. This difference of amplitude and the obtained results this work and the works of Kjartansson et al. 7,12 can be attributed to the difference in electrodes size used, as well as the difference of phase charge. It is known that the current density determines the physiologic and therapeutic effects derived of the electric stimulation ${ }^{31}$. Although Kjartansson 
et al. ${ }^{7,12}$ didn't mention in their works the electrodes size, Atalay et al. ${ }^{14}$ used electrodes measuring 4 x $4 \mathrm{~cm}$, what corresponds to an area of $16 \mathrm{~cm}^{2}$. The electrodes used in the present study presented $4,2 \times 1,5 \mathrm{~cm}$, totaling an area of 6,3 $\mathrm{cm}^{2}$. Electrodes with these dimensions were opted for a better adaptation to the size of the used flap. In such case, the current density used in the study of Atalay et al. ${ }^{14}$ was $1,25 \mathrm{~mA} / \mathrm{cm}^{2}$ $(\mathrm{d}=\mathrm{I} / \mathrm{a})$ and the one used in this study was $2,38 \mathrm{~mA} / \mathrm{cm}^{2}$. Although the current amplitude in this study was lower (15 $\mathrm{mA}$ ) than the used by Kjartansson et al. ${ }^{7,12}$ and Atalay et al. ${ }^{14}$ (20 mA), the density was larger than the one used by Atalay et al. ${ }^{14}$. This difference among the current densities maybe has contributed to the similarity among the results in relation to the improvement of the flaps viability.

Another factor that might have exercised influence in the results is the fact that the foresaid authors have used monophasic pulsed current (unidirectional), that presents smaller phase load than a biphasic current when it is compared to the same amplitude and pulse duration. Using current amplitude of $20 \mathrm{~mA}$ and monophasic pulse with duration of $0,2 \mathrm{~ms}$, it is obtained a phase charge of $4 \mu \mathrm{C}$ ( $q=\mathrm{I} . \mathrm{t}$ ). In this study, as biphasic pulse was used with amplitude of $15 \mathrm{~mA}$ and duration of 0,2 ms, it was applied in the flaps a phase charge of $6 \mu \mathrm{C}(q=2(\mathrm{I} . \mathrm{t}))$. Once again, this observation points to the explanation of the similarity of results obtained with different amplitudes.

However, the importance of the current amplitude in the improvement of the viability of skin flaps is not accepted in a unanimous way in the literature. Niina et al. ${ }^{6}$, using TENS with frequencies of $2 \mathrm{~Hz}$ and $80 \mathrm{~Hz}$ and amplitudes of 2, 10 and $20 \mathrm{~mA}$, concluded that what is really important is the use of high frequency $(80 \mathrm{~Hz})$, giving no importance to the amplitude used. These results should be analyzed cautiously, once these authors used a small number of animals for group and this result doesn't find support in other published works 7, 12, 14, 15, 17, 18 .

The electrostimulation, used with analgesic purposes or for increasing the blood flow, can be administered percutaneously - through needles or medullar implants ${ }^{6,32}$ - or transcutaneously - directly on the skin without the breaking up of the same ${ }^{25,26}$. In this study, the electric stimulation was accomplished transcutaneously through surface electrodes, once it is a non-invasive method, having no need of new operative intervention for implant or retreat of electrodes. Besides, Niina et al. ${ }^{6}$ demonstrated that the electrical stimulation through surface electrodes was effective in the increase of the viability of musculocutaneous flaps, unlike the stimulation accomplished through needles (electroacupuncture).

The electrodes were positioned in the base of the flap, according to some works ${ }^{6,7,12,14,15,16,17,18,30}$, because the affluence of the blood vessels responsible for the nutrition of the flap happens in this region. The distance between the electrodes was $1,5 \mathrm{~cm}$. It is known that they should not be positioned very close to each other, so that the electrical current does not pass extremely superficially on the tissue. In none of the consulted works the distance between the electrodes was described, what makes it difficult to reproduce these studies. The pulse duration was fixed in $200 \mu \mathrm{s}$, according to some works $6,7,12,14,15,17,18,30$. In several other works this time is not mentioned ${ }^{13,33,34}$. It is known that with this time it is possible to obtain sensory or motor responses, depending on the current's amplitude. With the amplitude of $15 \mathrm{~mA}$, discreet muscular contractions were observed in the flap. This is important to try to transpose this type of stimulation for patients submitted to skin flaps, where the same ones should feel a strong paresthesia ${ }^{15-17}$, and it could have the presence of discreet muscular fasciculations. The increase of the blood flow has been demonstrated with sensorial and motor stimulation, although more recent works have evidenced the increase of the circulation only when enough intensity was used to produce muscular contractions ${ }^{25,28,35,36}$. It is necessary to be cautious when analyzing these works, once many were accomplished in healthy individuals, with no alteration in the threshold of the nerve activation on these individuals.

Although in this study the mensuration of the blood flow of the skin was not accomplished, the increase of the flap viability of the stimulated groups was probably due to its increase. It is known that TENS has the capacity to increase the cutaneous blood flow; however, the exact mechanism on how this happens is still unknown. Several hypotheses to explain this discovery have been described in literature. The first is that TENS, through the stimulation of the large-diameter mechanosensitive fibers, may cause an inhibition of the sympathetic vasocontrictory neurons, resulting in a cutaneous vasodilation. Several authors have been trying to demonstrate the effects of electric stimulation on the sympathetic nervous system. Although some of those have alleged that there is an increase or no alteration of the sympathetic responses ${ }^{37,38}$, the majority has observed a sympathetic inhibition effect ${ }^{23,33,39}$. The other - and more accepted theory - consists in the liberation of some neuropeptides as the substance $\mathrm{P}$ and calcitonin generelated peptide (CGRP), which are found in the terminations of afferent A delta and C-fibers ${ }^{7,12,14}$. Those peptides can be liberated through the antidromic stimulation - also called the axon reflex. The following subject is now put in question: will the current's amplitude used (15 mA) be enough for the stimulation of this type of fiber? It is known that the stimulation occurs in the following order: sensory, motor and painful. Based on this principle, when it has a sensory or motor stimulation, there is no activation of nociceptive $\mathrm{A}$ delta and C-fibers. However, when a lesion occurs, just as the operative incision, the pain threshold can be reached immediately after the sensitive stimulation, that is to say, before the motor threshold. Another possible explanation for the stimulation of this fiber type would be the interaction of the Aâ-fiber through interneurons ${ }^{40,41}$.

Aside from these peptides (substance P and CGRP), Kaada et al. ${ }^{25}$ found a relationship between TENS and the liberation of vasoactive intestinal polypeptide (VIP). According to the authors, there may be a relationship between the liberation of this peptide and the cutaneous vasodilation. Cramp et al. ${ }^{36}$ hypothesis's for increase blood flow is the muscle pump or an increase in metabolic demand 
in stimulated muscles. A new mechanism for increase flap viability is the opioids administration ${ }^{42}$. It is know that TENS can release some kinds of opioids. Then this may be a new theory about the effects of TENS on flap viability also contributing for increase in blood flow. However this hypothesis still needs to be investigated.

\section{Conclusion}

The amplitude of $15 \mathrm{~mA}$ presented a lower necrotic area than control group and Transcutaneous Electrical Nerve Stimulation was efficient in increasing the random skin flap viability.

\section{References}

1. Ferreira LM. Retalhos Cutâneos. In Ferreira LM, editor. Manual de Cirurgia Plástica. 1ed. São Paulo: Atheneu; 1995. p 45-62.

2. Kerrigan CL. Skin flap failure: pathophysiology. Plast Reconstr Surg. 1983; 72:766-77.

3. Davis ER, Wachholz JH; Jassir D, Perlyn CA, Agrama $\mathrm{MH}$. Comparison of topical anti-ischemic agents in salvage of failing random-pattern skin flaps in rats. Arch Facial Plast Surg. 1999; 1:27-32.

4. Duarte SI, Gomes, HFC, Ferreira LM. Effect of dimethyl sulphoxide on necrosis of skin flaps in rats. Can J Plast Surg. 1998; 6:93-7.

5. Jurell G, Jonsson, CE. Increased survival of experimental skin flaps in rats following treatment with antiadrenergic drugs. Scand J Plast Reconstr Surg. 1976; 10:169-72.

6. Niina $Y$, Ikeda K, Iwa M, Sakita M. Effects of electroacupuncture and transcutaneous electrical nerve stimulation on survival of musculocutaneous flap in rats. Am J Chin Med. 1997; 25:273-80.

7. Kjartansson J, Lundeberg T, Samuelson UE, Dalsgaard J. Transcutaneous electrical nerve stimulation (TENS) increases survival of ischemic musculocutaneous flaps. Acta Physiol Scand. 1988; 134:95-9.

8. Jansen G, Lundeberg T, Samuelson UE, Thomas M. Increased survival of ischemic musculocutaneous flaps in rats after acupuncture. Acta Physiol Scand. 1989; 135:555-8.

9. Krag C, Taudorf U, Siim E, Bolund S The effect of pulsed electromagnetic energy (Diapulse) on the survival of experimental skin flaps. Scand J Plast Reconstr Surg. 1979; 13:377-80.

10. Amir A, Solomon AS, Giler S, Cordoba M, Hauben DJ. The influence of helium-neon laser irradiation on the viability of skin flaps in the rat. Br J Plast Surg. 2000; 53:58-62.

11. Reinish JF, Myers MB. Survival of experimental flaps pretreated with low-intensity direct current electrical delay. Surg Forum. 1974; 25:522-3.

12. Kjartansson J, Lundeberg T, Samuelson UE, Dalsgaard J, Hedén P. Calcitonin gene-related peptide (CGRP) and transcutaneous electrical nerve stimulation (TENS) increase cutaneous blood flow in a musculocutaneous flap in the rat. Acta Physiol Scand. 1988; 134:89-94.

13. Im JM, Lee WPA, Hoopes JE. Effect of electrical stimulation on survival of skin flaps in pigs. Phys Ther.
1990; 70:37-40.

14. Atalay C, Koçkaya EA, Çetin B, Kismet K, Akay MT. Efficacy of topical nitroglycerin and transcutaneous electrical nerve stimulation on survival of randompattern skin flaps in rats. Scand J Plast Reconstr Surg Hand Surg. 2003; 37:10-13.

15. Kjartansson J, Lundeberg T, Körlof B. Transcutaneous electrical nerve stimulation (TENS) in ischemic tissue. Plast Reconstr Surg. 1988; 81:813-5.

16. Lundeberg T, Kjartansson J, Samuelsson U. Effect of electrical nerve stimulation on healing of ischemic skin flaps. Lancet. 1988; 24:712-14.

17. Kjartansson J, Lundeberg T. Effects of electrical nerve stimulation (ENS) in ischemic tissue. Scand J Plast Reconstr Hand Surg. 1990; 24:129-34.

18. Liebano RE, Ferreira LM, Sabino Neto M. The effect of the transcutaneous electrical nerve stimulation on the viability of random skin flaps in rats. Can J Plast Surg. 2002; 10:151-4.

19. Liebano RE, Ferreira LM, Sabino Neto M. Experimental model for transcutaneous electrical nerve stimulation on ischemic random skin flap in rats. Acta Cir Bras. 2003; 18:54-9.

20. Sasaki GH, Pang CY. Hemodinamics and viability of acute neurovascular island skin flap in rats. Plast Reconstr Surg. 1980; 65:152-8.

21. Cheing GL, Hui-Chan CW. Transcutaneous electrical nerve stimulation: nonparallel antinociceptive effects on chronic clinical pain and acute experimental pain. Arch Phys Med Rehabil. 1999;80(3):305-12.

22. Scudds RJ, Helewa A, Scudds RA. The effects of transcutaneous electrical nerve stimulation on skin temperature in assintomatic subjects. Phys Ther. 1995; 75:622-8.

23. Owens S, Atkinson ER, Lees DE. Thermographic evidence of reduced sympathetic tone with transcutaneous nerve stimulation. Anesthesiology. 1979; 50:62-5.

24. Kaada B. Vasodilation induced by transcutaneous nerve stimulation in peripheral ischemia (Raynaud's phenomenon and diabetic polyneuropathy). Eur Heart J. 1982; 3:303-14.

25. Kaada B, Olsen E, Eielsen O. In search of mediators of skin vasodilation induced by transcutaneous nerve stimulation: III. Increase in plasma VIP in normal subjects and in Raynaud's disease. Gen Pharmacol. 1984; 15:107-13.

26. Kaada B, Helle KB. In search of mediators of skin vasodilation induced by transcutaneous nerve stimulation: IV. In vitro bioassay of the vasoinhibitory activity of sera from patients suffering from peripheral ischemia. Gen Pharmacol. 1984; 15:115-22.

27. Lundeberg T, Eriksson S, Malm M. Electrical nerve stimulation improves healing of diabetic ulcers. Ann Plast Surg. 1992; 29:328-31.

28. Debreceni L, Gyulai M, Debreceni A, Szabó K. Results of transcutaneous electrical stimulation (TES) in cure of lower extremity arterial disease. Angiology. 1995; 46:613-18.

29. Baker LL, Chambers R, Demuth SK, Villar F. Effects of electrical stimulation on wound healing in patients with diabetic ulcers. Diabetes Care. 1997; 20:405-12.

30. Cosmo P, Svensson H, Bornmyr S, Wikström S. Effects of transcutaneous nerve stimulation on the 
microcirculation in chronic leg ulcers. Scand J Plast Reconstr Hand Surg. 2000; 34:61-4.

31. Starkey C. Agentes elétricos. In: Starkey C, ed. Recursos terapêuticos em fisioterapia. São Paulo: Editora Manole; 2001. p.176-276.

32. Croom JE, Foreman RD, Chandler MJ, Barron KW. Cutaneous vasodilation during dorsal column stimulation is mediated by dorsal roots and CGRP. Am J Physiol. 1997; 242:H950-7.

33. Abram ES, Asiddao CB, Reynolds AC. Increased skin temperature during transcutaneous electrical stimulation. Anesth Analg. 1980; 59:22-5.

34. Dooley DM, Kasprak M. Modification of blood flow to the extremities by electrical stimulation of the nervous system. South Med J. 1976; 69:1309-11.

35. Sherry JE, Oehrlein KM, Hegge KS, Morgan BJ. Effect of burst-mode transcutaneous electrical nerve stimulation on peripheral vascular resistance. Phys Ther. 2001; 81:1183-91.

36. Cramp FL, McCullough GR, Lowe AS, Walsh DM. Transcutaneous electric nerve stimulation: the effect of intensity on local and distal cutaneous blood flow and skin temperature in healthy subjects. Arch Phys Med
Rehabil. 2002; 83:5-9.

37. Ebersold ML, Laws ER, Albers JW. Measurements of autonomic function before, during, and after transcutaneous stimulation in patients with chronic pain and in control subjects. Mayo Clin Proc. 1977; 52:228-32.

38. Wong RA, Jette PV. Changes in sympathetic tone associated with different forms of transcutaneous electrical nerve stimulation in healthy subject. Phys Ther. 1984; 64:478-82.

39. Linderoth B, Gunasekera L, Meyerson BA. Effects of sympathectomy on skin and muscle microcirculation during dorsal column stimulation: animal studies. Neurosurgery. 1991; 29:874-9.

40. Cervero F, Laird JMA. Mechanisms of touch-evoked pain (allodynia): a new model. Pain. 1996; 68:13-23.

41. Garcia-Nicas E, Laird JM, Cervero F. Vasodilation in hyperalgesic rat skin evoked by stimulation of afferent A beta-fibers: further evidence for a role of dorsal root reflexes in allodynia. Pain. 2001; 94:283-91.

42. Kiumehr S, Demehri S, Rabbani S, Amanpour S, Mohagheghi M.A, Dehpour A.R. Preconditioning of the rat random-pattern skin flap: modulation by opioids. $\mathrm{Br}$ J Plast Surg. 2005; 58:58-64.

\section{Correspondence:}

Richard Eloin Liebano

Plastic Surgery Division

Rua Napoleão de Barros, 715/4 andar

04024-002 São Paulo - SP Brazil

Phone: (55-11)5576-4118

Fax:(55-11)5571-6579

liebano@gmail.com
Conflict of interest: none Financial source: CAPES

Received: December 12, 2005

Review: January 18, 2006

Accepted: February 14, 2006

\section{How to cite this article:}

Liebano RE, Abla LEF, Ferreira LM. Effect of high frequency transcutaneous electrical nerve stimulation on viability of random skin flap in rats. Acta Cir Bras. [serial on the Internet] 2006 May-June;21(3). Available from URL: http://www.scielo.br/acb 